\title{
Exchange Rates and Inflation Rates Convergence in ECOWAS
}

\author{
Amath Ndiaye \\ FASEG, University C. A. Diop Dakar, Dakar, Senegal \\ Email: amathndiay@gmail.com
}

How to cite this paper: Ndiaye, A. (2021). Exchange Rates and Inflation Rates Convergence in ECOWAS. Modern Economy, 12, 1726-1747.

https://doi.org/10.4236/me.2021.1212088

Received: September 19, 2021

Accepted: November 30, 2021

Published: December 3, 2021

Copyright $\odot 2021$ by author(s) and Scientific Research Publishing Inc. This work is licensed under the Creative Commons Attribution International License (CC BY 4.0).

http://creativecommons.org/licenses/by/4.0/

(c) (i) Open Access

\begin{abstract}
The objective of this study is to see, among ECOWAS countries, if the difference between the fixed exchange rate regime of the WAEMU countries on the one hand and the flexible regimes of the WAMZ countries on the other hand, is a factor of non-convergence of inflation rates. To do so, we have first applied the Granger causality tests to look at the causality between exchange rate and inflation; then we have used an inflation differential model (IDM) to identify the factors of convergence or non-convergence of inflation rates between WAEMU and WAMZ. Our results show that WAMZ countries, due to their flexible exchange rate regimes, are subject to exchange rate pass-through (ERPT), unlike their WAEMU neighbours. Moreover, the results of the estimates of the inflation differential model (IDM) reveal that neither the evolution of the output nor that of the money supply, on both sides, explain the non-convergence of the inflation rates between WAEMU and WAMZ countries, but they show that the non-convergence of the inflation rates is significantly linked to the difference in the evolution of the exchange rates.
\end{abstract}

\section{Keywords}

Exchange Rate Pass-Through, Convergence, Inflation ECOWAS

\section{Introduction}

The fifteen states of the West African Economic Community (ECOWAS), on the one hand, are made up of the countries of the West African Economic and Monetary Union (WAEMU) and Cape Verde, which have a fixed exchange rate pegged to Euro and, on the other hand, of the English-speaking countries and Guinea, which have opted for a floating exchange rate regime. See country list in Annex.

Through their desire to develop the implementation of the ECOWAS mone- 
tary integration scheme, the non-WAEMU countries decided to set up a second monetary zone called the West African Monetary Zone (WAMZ). To this end, an institutional framework was created, focusing on the organization of macroeconomic convergence, the success of which should eventually lead to the merger of this zone with WAEMU to create the single ECOWAS monetary zone, initially planned for 2004, postponed to 2020 and then to 2027.

However, the inflation gap between WAEMU and WAMZ, from 2000 to 2020, seems to jeopardize the convergence objective of the ECOWAS economies and the chances of creating a single monetary zone.

Our study seeks to innovate in its approach; it is not just about verifying the existence or not of an inflation convergence, as most studies of convergence in ECOWAS have already done, but seeks to find the determinant factors.

This has given rise to the issue of the relationship between inflation and exchange rate regime. So, the process of economic integration of ECOWAS countries should be analyzed through the triptych "exchange rate-inflation-convergence" which provides the theoretical framework for our study.

This study is focusing on the exchange pass through into prices and its impact on ECOWAS inflation convergence. The exchange rate pass-through into domestic prices is the effect of the variation of the nominal exchange rate on prices through the imported products channel. The exchange rate pass-through can be measured at both the micro and the macroeconomic levels, but in this study we will confine ourselves to the macroeconomic approach.

The overall objective of our research is to see whether there is a causality relationship between the differences in exchange rate regimes and the non-convergence of inflation rates. Indeed, WAEMU countries with fixed exchange rate regimes pegged to the Euro have lower inflation rates than WAMZ countries with flexible exchange rate regimes.

The specific objectives of our research are:

- To do causality tests between exchange rates and inflation rates.

- To see whether the difference between the inflation rates of WAEMU and WAMZ can be explained in a stochastic relationship by the difference between their exchange rates;

The rest of this paper is organized as follows. We start by the analysis of the evolution of inflation in ECOWAS, then we do the literature review before presenting the methodology. Last but not least, we will analyze the results before concluding.

\section{The Evolution of Inflation in the ECOWAS}

Since the adoption of the Economic and Monetary Cooperation Programme in 1978 , with the objective of reducing inflation rates to 5\%, WAEMU countries have outperformed their WAMZ counterparts in terms of inflation control. Indeed, the former have achieved the objective while the latter are still struggling to get closer to it. For example, in 2013, the worst performer in WAEMU was 
Côte d'Ivoire with 2.6\% while the best performer in WAMZ was Gambia with $5.7 \%$.

As it can be seen in Figure 1, since the adoption of the Economic and Monetary Cooperation Programme in 1978, WAMZ countries have failed to achieve the $5 \%$ inflation target, while WAEMU countries have been below this threshold since 1998. The best performance of WAMZ countries was in 2007 when they achieved an average inflation rate of 5.3\%. Unfortunately, since the international financial crisis of 2007-2008, inflation in WAMZ countries has been rising steadily to reach $11.3 \%$ in 2019 while continuing to fall in WAEMU countries to reach a negative rate of $-0.8 \%$.

Indeed in 2007-2008, the ECOWAS countries have been strongly impacted by the tensions on the international foodstuffs and energy market. In fact, the countries of that area have had to face important inflationary pressures. The large dependence of these countries on imported foodstuffs as against local production has exacerbated the situation. At the end of 2008, all ECOWAS countries except Senegal recorded high inflation rates. The end of period of the inflation rate in the area moved from $5.8 \%$ in 2007 to $13.0 \%$ in 2008. Within the ECOWAS area, inflation stood at $8.5 \%$ versus $2.9 \%$ in 2007 . The most affected ECOWAS countries were Niger, Burkina, Benin and Togo. As for the WAMZ countries, the inflation rates have more than doubled to reach $11.58 \%$ in 2008 . Within the WAMZ, all the countries have been deeply affected with the exception of The Gambia.

Thus, since 2007, inflation rates between the two zones have not converged due to the WAMZ countries not being able to reach the EU target of $5 \%$.

Inflation rose again since 2016 due to the sharp increase in commodities price index in Nigeria. The direct and indirect effects of the significant depreciation of

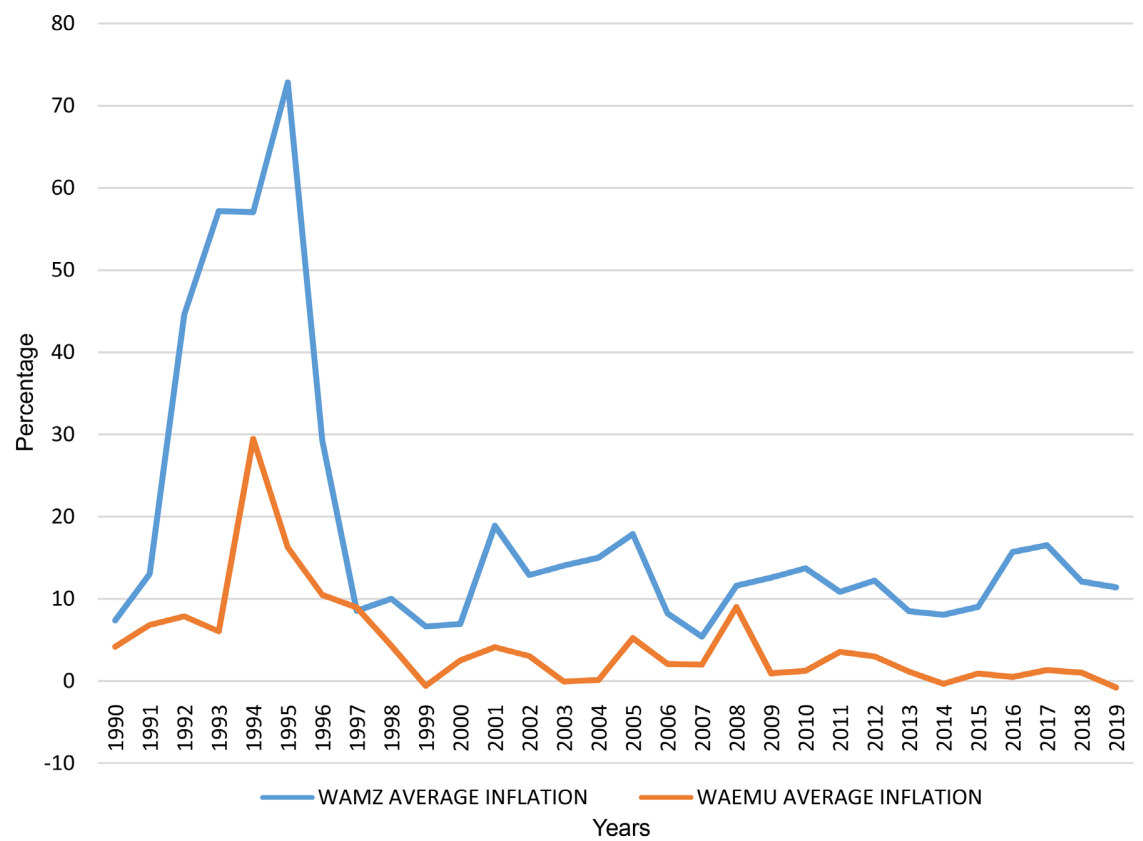

Figure 1. Inflation in WAEMU and WAMZ in \%. Source: Author's calculations. 
the Naira, alongside higher electricity and fuel prices, explain mainly the spike in inflation in this country which accounts for $67 \%$ of ECOWAS GDP.

In addition, the protracted price hike in Ghana, which is at approximately $17 \%$ in 2016 contributed to a situation of uncertainty regarding the reduction and stabilization of the average inflation rate within ECOWAS. Beyond the specific case of those two countries, which is arguably due to a slowdown in economic activity, it is particularly interesting to note the heterogeneity of inflation dynamics between WAEMU and Cabo Verde on the one hand and WAMZ on the other hand, as well as inflation disparities between countries of the latter zone.

Two strong trends can be identified. All WAEMU countries have price levels that would be permanently pegged below the long-term 5\% threshold (see Figure 1). On the other hand, no WAMZ country would have an inflation rate below the $5 \%$ threshold.

In the recent period, the divergence in inflation rates between the two zones is more relevant. Inflationary pressures in West Africa moderated in 2018 and 2019 but the impact of COVID-19 pandemic could reverse the gains. Average inflation in ECOWAS fell to 8.5 percent in 2019 from 9.4 percent the previous year. As we have noticed it, Inflation is generally lower in the WAEMU region than in the WAMZ countries. In the former group, it averaged less than 1 percent in 2019 compared with 10 percent in the WAMZ group.

The annual inflation rate of ECOWAS is projected to reach an average of 9.5 percent in 2021. Among the member states, Sierra Leone and Nigeria (WAMZ country members) were expected to record the highest rate of inflation, reaching 15.5 percent and 12.7 percent, respectively. On the other hand, inflation in Côte d'Ivoire (WAEMU country member) is estimated at 1.4 percent, the lowest compared to the other countries. To conclude we can say that, from the year 2000 to 2020 , the inflation rates of WAMZ and WAEMU have been divergent.

\section{Literature Review}

\subsection{Inflation and Exchange Rate Pass-Through (ERPT)}

The conclusions of those who have worked on a macroeconomic approach to ERPT are presented in the works of Devereux \& Yetman (2000), Hahn (2003), Frankel, Parsley and Wei (2005), Dornbush (1987), Rowland (2003), Mc Farlane (2002), Garcia and Restrepo (2001) and Kiptui, Ndolo and Kaminchia (2005). These studies showed that for a 6-month horizon the ERPT coefficient was higher in developing or emerging countries than in developed countries, that the degree of pass-through was positively correlated with the share of imports in GDP and that the inflationary environment played a significant role in the value and the evolution of the pass-through coefficient. Moreover, the pass-through coefficient of developed countries has tended to weaken since the 1990s.

The correlation between the degree of ERPT and the import ratio is highlighted by An, Wang et al. (2011), in a study of OECD countries. Applying the VAR me- 
thod, they show that the pass-through coefficient is higher in smaller economies and/or with higher import-to-GDP ratios.

Krugman (1986), dealing with quarterly data on US imports for the period $1980-1983$, found that $35 \%-40 \%$ of the appreciation of the dollar was not reflected in a fall in the prices of imported goods.

The estimate made for the period 1975-1999 for the OECD countries by Campa and Goldberg (2002) defends the partial ERPT hypothesis for the long term but not for the short term.

In the case of emerging countries, a strong depreciation does not necessarily imply a significant increase in domestic prices because, in a period of economic recession, firms do not adjust their prices proportionally to the increase in costs. This was verified in 1997-98 during the East Asian currency crisis; inflation did not rise after the sharp depreciation of East Asian currencies (Takatoshi \& Sato, 2008). These authors, using a VAR model, showed that the ERTP effect on domestic prices was small except in Indonesia.

For small economies in general, such as those in ECOWAS, the unidirectional causality of the exchange rate on inflation often holds. This was shown by Babar Zaheer Butt, Kashif Ur Rehman, Muhammad Azeem, Butt, Rehman, and Azeem (2010) by applying the Granger causality test and the Johansen and Juselius cointegration test to the case of Pakistan.

Razafimahefa (2012), analyzing The ERPT and its determinants in sub-Saharan Africa, found an average elasticity of 0.4; however, they say, it is lower in high-income countries, and/or those with more flexible exchange rate regimes.

The study by Akofio-Sowah (2009) which covered fifteen Sub Saharan African Countries and 12 Latin American countries demonstrated, using annual data, that the ERPT could be mitigated by a low inflationary environment. In Africa, the countries of the Common Market for Eastern and Southern Africa (COMESA) have the highest inflation rates and ERPT coefficients, 25 to 50 times higher than those of the West African Economic and Monetary Union or the Economic Community of Central African States. This illustrates that African countries with fixed exchange rate regimes are less exposed to ERTP than countries with flexible exchange rate regimes.

Tarawalie, Sissoho, Conte and Ahortor (2012) using a general equilibrium model, studied the effects of the exchange rate on inflation and economic growth between 1981 and 2010 for all WAMZ countries. Using the VAR method, they concluded that the exchange rate has a significant impact on inflation in all WAMZ countries

Rraji (2013) also, using the VAR method, applied to quarterly data from 2000 to 2010 , showed that the pass-through effect contributed an average of $26 \%$ to consumer price changes in The Gambia, Ghana, Nigeria and Sierra Leone.

Frimpong and Adam (2010) using annual data, also confirmed the existence of the pass through effect in Ghana. A weak effect in the long term but significant in the short term.

Alagidede, George, \& Anokye (2008), using a vector error correction model 
(VECM), with quarterly data, showed that a $1 \%$ depreciation of the currency-in The Gambia, Nigeria, and Sierra Leone-resulted in a quarterly increase in prices of at least $0.8 \%$ and during 8 quarters.

Aliyu, Yakub, Sanni and Duke (2010), using an error correction model for Nigeria, show that a $1 \%$ shock to the exchange rate has a positive impact of $14.3 \%$ on import prices and $10.5 \%$ on consumer prices over four quarters.

\subsection{On Economic Convergence of ECOWAS Countries}

The concept of convergence based on neo-classical growth models (Solow, 1956) means that, in the long term, the growth rate of income or output per capita of an economy tends towards a stationary state, regardless of the initial conditions in which the economy was. In the stationary state, the growth rate is equal to the rate of technical progress, assumed to be identical for all economies.

The estimation of the $\beta$-convergence model (Barro \& Salai-i-Martin, 1995) in cross-section is usually used to assess the relevance of the convergence concept. Thus, $\beta$-convergence can be absolute (unconditional) or conditional. It is absolute when the economies are structurally identical and thus have the same stationary state: in this case, the economies, even if characterized by different initial conditions, will progress towards the same stationary state. On the other hand, $\beta$-convergence is conditional when the economies are different and they will then converge towards their own stationary state. The latter case actually corresponds to the assumption framework of the neo-classical growth model. Therefore, if economies converge to different states, the phenomenon of economies catching up is by no means guaranteed, even if some "poor" economies grow faster than some "rich" economies. Only in the case of absolute $\beta$-convergence the predictions in terms of catching up are valid.

The idea of convergence can also be based on the presence of an adjustment mechanism over time of economic variables towards a reference value $\left(y^{*}\right)$ considered as an attractor. Assuming that $y_{t}=\beta *\left(y_{t-1}-y^{*}\right)$, we say that there is convergence if there is a mechanism for correcting deviations from the reference value, i.e. if the $\beta$ coefficient is negative and statistically significant.

It is possible to measure convergence from an indicator such as the variance or the standard deviation of several series. Applying this indicator, Diop (2002) noted that the ECOWAS economies are part of an overall process of nominal convergence, with a reduction over time, particularly from 1995 . He shows that the evolution of the standard deviation of the inflation rates of ECOWAS countries was relatively erratic between 1975 and 1990, even if an overall convergence of inflation rates is noted over the period 1990-2001.

Ndiaye \& Korsu (2014), having conducted convergence tests on data from 1975 to 2010 and using the Johansen method of cointegration, argued that no nominal convergence could be demonstrated in interest rates, budget deficits and inflation rates, both between WAMZ countries and between all ECOWAS countries.

Tanimoune and Semedo (2011) showed on the one hand a clear nominal con- 
vergence of inflation rates and on the other hand a significant variability of national relative prices. They show that the Beta coefficient is negative and significant in all cases for the 1986-2009 time period. Their results indicated an inflation convergence towards the ECOWAS long term equilibrium level and provide a comparison with the 3\% WAEMU and 5\% ECOWAS inflation targets.

The WAEMU countries particularly are in a dynamic of unquestionable nominal convergence, especially in terms of inflation. Dramani (2010), having applied the $\beta$-convergence test over the 1965-2000 period, found that they were converging in inflation, budget deficit and debt ratio.

However, although the WAEMU countries remain below the 5\% ECOWAS inflation target since 2000, inflation rates among them have instead entered a process of divergence. Indeed, more than $66 \%$ of the variability of the inflation differential is explained by asymmetric shocks, hence highlighting the structural economic differences of WAMU member countries. This is a finding from Diop and Thiaw (2010).

\section{Methodology}

\section{Stationarity and Cointegration Tests of the Variables}

Stationarity test assures non spurious result; co-integration captures equilibrium long-run relationships between cointegration variables, and error correction mechanism is a means of reconciling the short-run behavior of an economic variable with its long-run behavior.

The order of integration of the variables is examined using the Augmented Dickey-Fuller (ADF) test statistic of unit roots.

After confirming order of integration of the variables, the study proceeds to test the long-run behaviour of economic variables through co-integration test. We use the (Pesaran, Shin, \& Smith, 2001) bounds cointegration test (Pesaran, Shin, \& Smith, 2001).

The Pesaran test is performed in two steps:

Step 1: Determine the optimal ARDL model

Step 2: Use the Fisher statistic to test for cointegration.

The decision rule is as follows:

- If the Fisher statistic is >the upper bounds I (1) then the variables are cointegrated.

- If the Fisher statistic is <lower bound I (0) then the variables are not cointegrated.

- If the Fisher statistic < lower bounds < upper bounds then no conclusion can be drawn.

Finally, the Engle-Granger Error Correction Model is used to estimate the model.

\subsection{The Causality Tests}

Although the ERPT hypothesis can be tested through a simple model that ig- 
nores the inflation effect on the exchange rate, we prefer the VAR approach as it is more appropriate to study the interaction between the exchange rate and inflation.

In econometrics, causality between two variables is usually studied in terms of forecast improvement according to Granger's approach (Engel \& Granger, 1987), or in terms of impulse analysis, according to Sims et al. (1990) principles. In Granger's sense, a series "causes" another series if knowledge of the past of the former improves the forecast of the latter. According to Sims, a series can be recognized as causal for another series if the innovations of the former contribute to the forecast error variance of the latter. Between these two main modes of statistical characterization of causality, Granger's approach will be retained in our research.

The basic of Granger's definition is the dynamic relationship between variables. It is stated in terms of improving the predictability of a variable. For Granger, temporal succession is central and causality cannot be discussed without taking time into consideration. Causality in Granger's sense can be formalized as follows: if we denote by $x_{t}$ and $y_{t}$ two stationary series; by performing the linear regression of $y_{t}$ on the past values of $y_{s}(s<t)$ and on the past values of $x_{s},(s<t)$, if we obtain significant coefficients, then the knowledge $x_{t}$ values can improve the prediction of $y_{i}$ we say that $x_{t}$ causes $y_{t}$ Instantaneous causality occurs when the current value of $x_{t}$ appears as an additional explanatory variable in the previous regression. Thus we propose to estimate the following model:

$$
\begin{gathered}
Y_{t}=a_{0}+a_{1} Y_{t-1}+\cdots+a_{p} Y_{t-p}+b_{1} X_{t-1}+\cdots+b_{p} X_{t-p}+u_{t} \\
X_{t}=c_{0}+c_{1} X_{t-1}+\cdots+c_{p} X_{t-p}+d_{1} Y_{t-1}+\cdots+d_{p} Y_{t-p}+v_{t}
\end{gathered}
$$

$Y=$ inflation rate

$X=$ nominal exchange rate

$u_{t}$ and $v_{t}$ are the error terms

We will test the null hypothesis H0: $a_{1}=a_{2}=\cdots=a_{p}=0$, against H1. H0 is the hypothesis that $X$ does not cause $Y$. So if $\mathrm{H} 0$ is rejected, we will say that $X$ (the exchange rate) causes $Y$ (the inflation rate). Similarly it will be tested H0: $d_{1}=d_{2}=\cdots=d_{p}=0$, against $\mathrm{H1}$; in this case also if $\mathrm{H0}$ is rejected, we will say that $Y$ (the inflation rate) causes $X$ (the exchange rate).

\subsection{Measuring the Convergence of Inflation Rates}

To assess the inflation rates convergence in ECOWAS countries, we will calculate the Sigma convergence and the Beta convergence.

\subsubsection{The Sigma Convergence}

It measures the degree of closeness, over time, between several individuals (economies), with regard to one or more indicators or criteria. In practice, we often observe the evolution of the dispersion of the series considered. Thus, it should be noted that there is convergence of the whole sample if this dispersion decreases; otherwise, there is divergence. As an indicator of dispersion, we generally consider sigma convergence as the variance or the standard deviation of the 
series.

The formula is given as follows:

Let $\pi_{i t}$ be the inflation level in year $t$ in ECOWAS country $i$, with $i=1, \cdots, n$; $\pi_{m t}$ the inflation mean rate of all countries in year $t$, then the sigma-convergence noted $\sigma_{t}$ is equal to:

$$
\sigma_{t}=\sqrt[2]{\sum_{1=n}^{n} \frac{\pi_{i t}-\pi_{m t}}{n}}
$$

From a graph, if $\sigma_{t}$ has a downward trend, it is concluded that the countries' inflation rates are (nominally) converging; otherwise, divergence will be observed.

\subsubsection{The Beta Convergence}

This involves estimating the following equation:

$$
\Delta \pi_{t}=\beta *\left(\pi_{t-1}-\pi_{c}\right)+\varepsilon_{t}
$$

$\pi_{t}=$ inflation rate; $\pi_{c}=$ inflation norm set (5\%) under multilateral surveillance within ECOWAS; $\varepsilon_{t}=$ the randomness or error term (assumed normally and independently distributed, constant variance and zero mean). If the estimated $\beta$ is statistically significant $(\beta \neq 0)$ and is negative, we say that there is convergence of the inflation rates of a country towards the Community inflation norm, i.e. the existence of a mechanism for adjusting the inflation rate towards the norm when it deviates from the norm following a shock.

\subsection{The Differential Inflation Model to Explain the Sigma Convergence}

The classical formulation of the models that have been used to test the phenomena of conditional convergence or divergence between regions is based on the work of Caselli et al. (1996).

Let:

$$
\log \left(\pi_{i t}\right)-\log \left(\pi_{i t-1}\right)=\beta \log \left(\pi_{i t-1}\right)+\phi X_{i, t}+\mu_{i}+\theta_{t}+\varepsilon_{i, t}
$$

$\pi_{i t}$ is the inflation rate of country $i$ in period $t$,

$X_{i, t}$ is all other determinants of inflation (exchange rate, supply shock, money supply),

$\mu_{i}$ is the country-specific effect that controls for differences and other determinants of inflation that are not captured in $X_{i, t}$,

$\theta_{t}$ is the specific effect to the study period and

$\varepsilon_{i, t}$ is the error term.

If $\beta<0$ and statistically significant then the hypothesis of conditional convergence is accepted as well as the conditional convergence between countries.

We draw on the above equation of Caselli et al. (1996) to assume that the inflation differential between two countries can be explained by their differences in the values of the determinants of inflation (money supply, exchange rate, gross 
domestic product, etc.).

It follows that the Sigma convergence of inflation (standard deviation of inflation between the two countries) can be a stochastic relationship of the standard deviations of money supply, exchange rate and gross domestic product.

To simplify we use the algebraic differences. Hence, for a given variable $x$, the algebraic difference between WAEMU and WAMZ values is measured (approximately) by the ratio of the average values i.e. $x=\frac{x_{\text {waemu }}}{x_{\text {wamz }}}$. Thus, the ESC model can be expressed in the following form:

$$
\begin{aligned}
& \mathrm{ESC}=\log \frac{\mathrm{INFL}_{\text {waemu }}}{\mathrm{INFL}_{\text {wamz }}} \\
& =a_{0}+a_{1} \log \frac{\mathrm{NER}_{\text {waemu }}}{\mathrm{NER}_{\text {wamz }}}+a_{2} \log \frac{\mathrm{GDP}_{\text {waemu }}}{\mathrm{GDP}_{\text {wamz }}}+a_{3} \log \frac{\mathrm{MON}_{\text {waemu }}}{\mathrm{MON}_{\text {wamz }}}+\varepsilon_{t}
\end{aligned}
$$

INFL $=$ average inflation rate;

$\mathrm{NER}$ = average exchange rate against the dollar;

$\mathrm{GDP}=$ average gross domestic product;

MON = average money supply;

The variables values are group averages. For example, $\mathrm{INFL}_{\text {waemu }}$ represents, for a given year, the average inflation rate in WAEMU. $\mathrm{INFL}_{\mathrm{wamz}}$ represents for a given year the average inflation rate in WAMZ. The ratio between these two values measures the inflation gap between the two zones. Thus the above model allows the analysis of inflation difference as a function of the difference in exchange rates, outputs and money supplies.

If $a_{p}>0$ then the variable $x_{p}$ in Equation (6) above is said to contribute to the inflation gap between WAEMU and WAMZ. For example, if $a_{1}>0$, this means that as long as the exchange rate gap between WAEMU and WAMZ increases the gap between their inflation rates increases and consequently the divergence (nonconvergence) of their inflation rates increases.

If $a_{p}<0$ then the variable $\mathrm{x}_{\mathrm{p}}$ in Equation (6) above is said to contribute to the convergence of inflation rates between WAEMU and WAMZ.

Our calculations and estimates are based on annual data from the World Bank's World Development Indicators (WDI). The following series have been used:

- GDP (constant 2010 US\$);

- Broad money (current LCU);

- Inflation, GDP deflator (annual \%);

- Inflation, consumer prices (annual \%);

- Official exchange rate (LCU per US\$, period average);

The period of study is $1990-2020$.

\section{Results and Analysis}

\subsection{Causality Tests}

Table 1 and Table 2 below concern the Granger causality tests between the 
Table 1. Granger causality test results for WAEMU. Lag: 1.

\begin{tabular}{|c|c|c|c|}
\hline \multirow[t]{2}{*}{ Pays } & \multirow[t]{2}{*}{ Test hypotheses } & $\begin{array}{l}\text { Time } \\
\text { Period }\end{array}$ & $\begin{array}{l}\text { Time } \\
\text { Period }\end{array}$ \\
\hline & & $1980-2012$ & $1980-2020$ \\
\hline \multirow{2}{*}{ Bénin $[\mathrm{BEN}]$} & NER does not Granger Cause INFL & 0.4472 & 0.0996 \\
\hline & INFL does not Granger Cause NER & 0.6596 & 0.3309 \\
\hline \multirow{2}{*}{ Burkina Faso $[\mathrm{BFA}]$} & NER does not Granger Cause INFL & 0.6369 & 0.1734 \\
\hline & INFL does not Granger Cause NER & 0.9738 & 0.3991 \\
\hline \multirow{2}{*}{ Côte d'Ivoire [CIV] } & NER does not Granger Cause INFL & 0.3766 & 0.0788 \\
\hline & INFL does not Granger Cause NER & 0.9385 & 0.3765 \\
\hline \multirow{2}{*}{ Guinée-Bissau [GNB] } & NER does not Granger Cause INFL & 0.7900 & 0.2343 \\
\hline & INFL does not Granger Cause NER & 0.3527 & 0.6597 \\
\hline \multirow{2}{*}{ Mali $[\mathrm{MLI}]$} & NER does not Granger Cause INFL & 0.3519 & 0.2765 \\
\hline & INFL does not Granger Cause NER & 0.7880 & 0.3970 \\
\hline \multirow{2}{*}{ Niger [NER] } & NER does not Granger Cause INFL & 0.5570 & 0.3682 \\
\hline & INFL does not Granger Cause NER & 0.8917 & 0.5648 \\
\hline \multirow{2}{*}{ Sénégal [SEN] } & NER does not Granger Cause INFL & 0.9451 & 0.1574 \\
\hline & INFL does not Granger Cause NER & 0.9452 & 0.2489 \\
\hline \multirow{2}{*}{ Togo [TGO] } & NER does not Granger Cause INFL & 0.2880 & 0.0651 \\
\hline & INFL does not Granger Cause NER & 0.7503 & 0.0874 \\
\hline
\end{tabular}

$\mathrm{NER}=$ nominal exchange rate, INFL = annual inflation rate. Decision Rule: If Prob $<5 \%$ the null hypothesis is rejected i.e. the counter hypothesis is accepted.

Table 2. Granger causality test results for WAMZ. Lag: 1.

\begin{tabular}{cccc}
\hline Pays & Test hyptheses & $1980-2012$ & $1980-2019$ \\
\hline \multirow{2}{*}{ Gambie [GMB] } & NER does not Granger Cause INFL & $0.0023^{* *}$ & 0.2434 \\
& INFL does not Granger Cause NER & 0.7306 & 0.7091 \\
Ghana [GHA] & NER does not Granger Cause INFL & $0.0024^{* *}$ & $0.0445^{*}$ \\
& INFL does not Granger Cause NER & 0.1436 & 0.6355 \\
& NER does not Granger Cause INFL & $0.0006^{* *}$ & 0.113 \\
Guinée [GIN] & INFL does not Granger Cause NER & 0.4857 & 0.121 \\
& NER does not Granger Cause INFL & $0.0832^{* *}$ & $0.0391^{*}$ \\
Libéria [LBR] & INFL does not Granger Cause NER & 0.8163 & 0.3504 \\
& NER does not Granger Cause INFL & $0.0183^{* *}$ & $0.0106^{*}$ \\
& & & $(1980-2016)$ \\
Nigéria [NGA] & INFL does not Granger Cause NER & 0.7619 & 0.3504 \\
\hline
\end{tabular}


Continued

\begin{tabular}{lccc}
\hline Sierra Leone [SLE] & NER does not Granger Cause INFL & 0.8961 & $\begin{array}{c}0.0409^{*} \\
(1980-2019)\end{array}$ \\
& INFL does not Granger Cause NER & 0.8918 & 0.7093 \\
\hline
\end{tabular}

*denotes rejection of the hypothesis at the 0.05 level; ${ }^{* *}$ denotes rejection of the hypothesis at the 0.01 level.

dollar/national currency exchange rate and the annual inflation rate from 1980 to 2020 .

The results prove significantly that the exchange rate is an important inflationary factor in the WAMZ countries (Gambia, Ghana, Guinea, Liberia, Nigeria, and Sierra Leone). The H0 hypothesis (NER does not cause INFL) is rejected in all WAMZ countries while it is not rejected in any WAEMU country. This is an evidence that ERPT to inflation is a reality in WAMZ and not in WAEMU.

The above results reject the null hypothesis Ho for all WAEMU countries. The exchange rate does not cause inflation in the Granger sense.

The above causality test results do not reject the null hypothesis Ho for the WAMZ countries. The exchange rate causes inflation, in the Granger sense, in the 6 WAMZ countries.

The results reflect the difference in exchange rate regimes between WAMZ on the one hand and WAEMU and Cape Verde on the other. The former are much more sensitive to the effect of exchange rate changes on prices than the latter. The WAEMU countries and Cape Verde with currencies pegged to the Euro are less exposed to imported inflation; they benefit from protection against economic shocks and the vicissitudes of the exchange markets that weaken the currencies of small economies.

\subsection{The Beta Convergence Results}

The Beta coefficients are negative but not significant. For the WAMZ countries whose inflation is above the $5 \%$ norm, this means that they are not converging towards this common norm. On the other hand, for WAEMU countries that are evolving below the norm, a negative Beta coefficient does not mean that there is no convergence towards the 5\% norm. (See estimations in Annex).

\subsubsection{Analysis of the Sigma Convergence}

The evolution of standard deviations ( $\sigma$ convergence) confirms the dynamics of decreasing inflation until the beginning of the 2000s but from this period onwards the trend is upwards (see Figure 2 below). From the results plotted in the graph below, it can be seen that the standard deviation of inflation rates actually decreased until 2004, thus reflecting the convergence dynamics of inflation rates within ECOWAS. However, from 2004 onwards, it can be observed that the trend is rather towards divergence and volatility of inflation rates. The main cause of this divergence and volatility comes from the WAMZ countries, which 


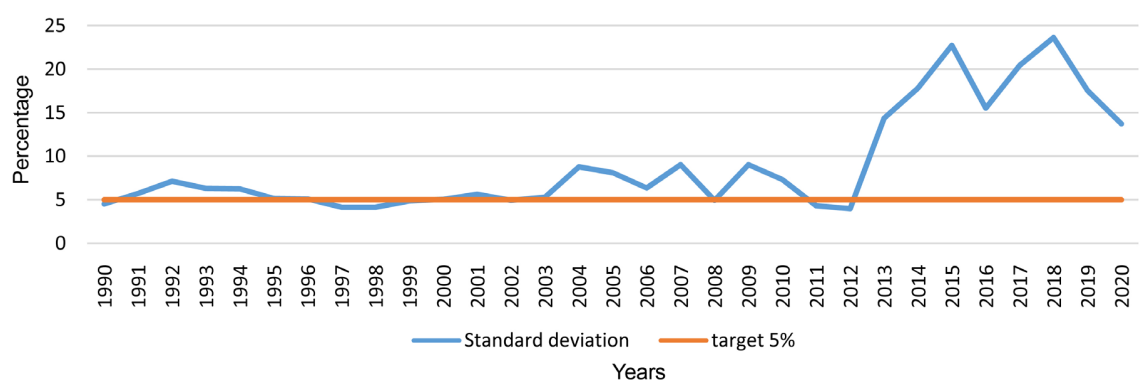

Figure 2. Ecowas inflation standard deviation. Source: Author's calculations.

are having difficulties in staying on course and achieving the Community objective of $5 \%$ inflation.

Comparing the WAEMU to the WAMZ, it can be seen that the two blocks have convergence problems as throughout the period the standard deviation has often exceeded 5\%. It has been increasing since 2010 and reached $8.6 \%$ in 2019 (see Figure 3 below).

Within the WAMZ, the divergence and instability of inflation rates become evident from the year 2000 onwards. The standard deviation is well above 5\% between 2000 and 2020, whereas the Community target is set at a maximum of $5 \%$ inflation (Figure 4).

On the other hand, in WAEMU and Cape Verde, the 5\% criterion is achieved; the standard deviation remains low as the different economies continue to converge downwards. Inflation remains low in WAEMU as does the standard deviation between countries in the union. See Figure 5 below.

Based on the evolution of standard deviations or sigma convergence, the analysis reveals that inflation rates in WAEMU and Cape Verde have not converged with those of WAMZ since the early 2000s. So, the difference between the exchange rate regimes is an important explanatory factor.

\subsubsection{Model Results}

Model (6) attempts to find an explanation for the divergence in inflation rates between WAEMU and WAMZ. As reported in the below Table 3 the variables of the model are not stationary in level except LRINF (the inflation rate ratio), that is why we estimated a two-stage error correction model (Engle-Granger ECM).

The unit root test result as presented in Table 4 shows that all the variables of interest were stationary at first difference except LRINF that was stationary at level. With the existence of variables being stationary at level and at first differencing, we proceeded to conducting a cointegration test to determine whether there is a long run equilibrating relationship among the variables.

The value of the Fisher statistic is equal to 22.774 (Table 5). As the Fisher statistic is greater than the upper bound values, we reject the null hypothesis of non-cointegration. The variables LRINF, LRMONEY, LRGDP AND LRCHANGE are cointegrated. 


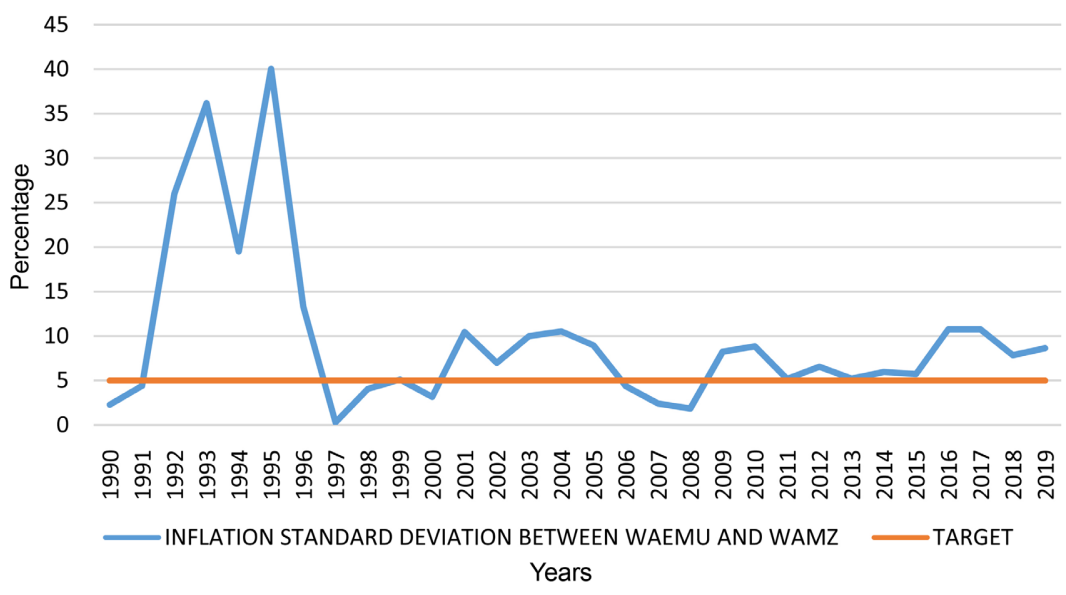

Figure 3. Waemu-Wamz inflation standard deviation. Source: Author's calculations.

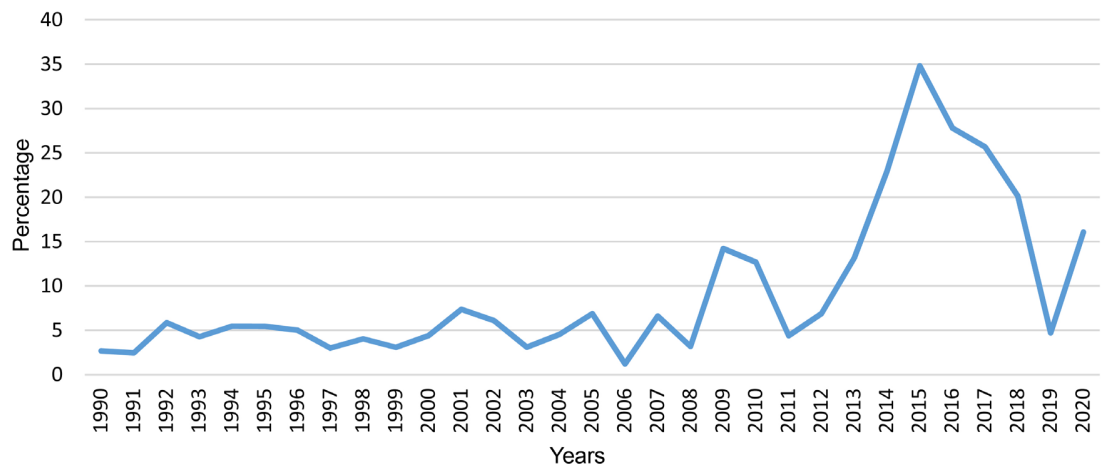

Figure 4. Standard deviation of Wamz inflation in \%. Source: Author's calculations.

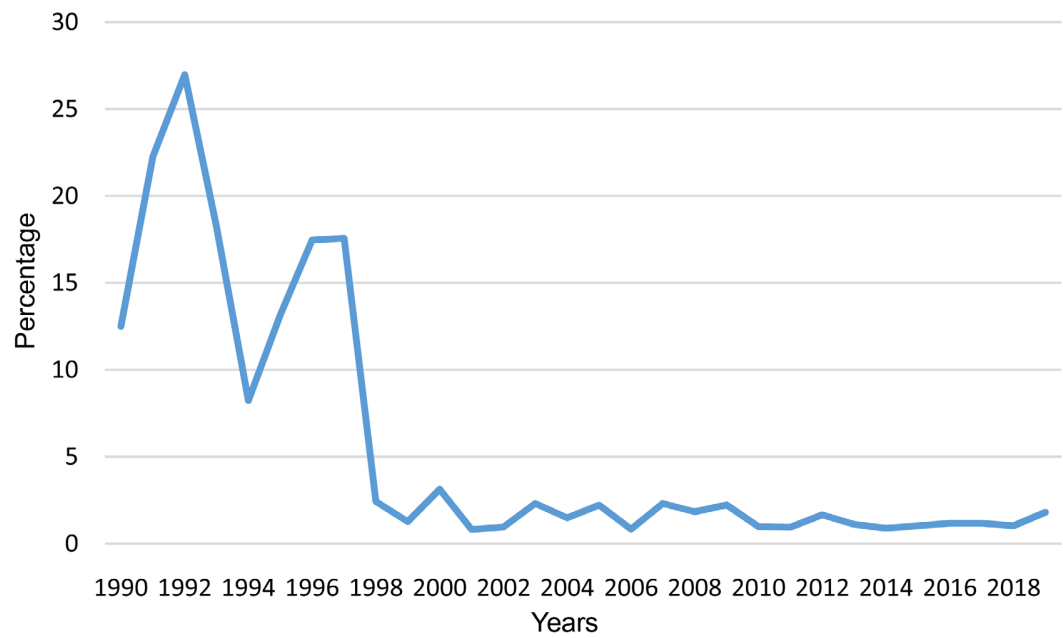

Figure 5. Waemu inflation standard deviation. Source: Author's calculations.

Table 3. Beta convergence 1991-2019.

\begin{tabular}{ccc}
\hline & Beta coefficients & Prob. \\
\hline WAEMU & -0.170259 & 0.6536 \\
WAMZ & -0.004968 & 0.9240 \\
\hline
\end{tabular}


Table 4. Unit root test statistics.

\begin{tabular}{cccc}
\hline Variables & ADF & Variables & ADF \\
\hline LRINF & -4.09 & DLRINF & -8.07 \\
LRCHANGE & -0.52 & DLRCHANGE & -8.18 \\
LRGDP & -1.71 & DLRGDP & -3.02 \\
LRMONEY & -2.21 & DLRMONEY & -4.74 \\
\hline
\end{tabular}

${ }^{\star} \mathrm{ADF} 5 \%$ critical value $=-2.96 ;{ }^{* *} \mathrm{ADF} 1 \%$ critical value $=-3.68$.

Table 5. Result of the Pesaran, Shin, \& Smith (2001) cointegration test.

\begin{tabular}{ccc}
\hline Variables & \multicolumn{2}{c}{ LRINF, LRMONEY, LRGDP LRCHANGE } \\
\hline Calculated F-stat & & $\mathbf{2 2 , 7 7 4}$ \\
Critical thresholds & Lower bounds & Upper bounds \\
$10 \%$ & 2.72 & 3.77 \\
$5 \%$ & 3.23 & 4.35 \\
$2,5 \%$ & 3.69 & 4.89 \\
$1 \%$ & 4.29 & 5.61 \\
\hline
\end{tabular}

Furthermore, following the Fully Modified Least Squares estimation there is a long run cointegration of the model variables and we notice that the exchange rate difference (LRCHANGE) has a positive and significant effect on the inflation difference (LRINF).

Equation R1: Cointegration equation deterministics:

\begin{tabular}{ccccc}
\hline \multicolumn{5}{c}{ Dependent Variable: LRINF } \\
\hline \multicolumn{5}{c}{ Method: Fully Modified Least Squares (FMOLS) } \\
\hline \multicolumn{5}{c}{ Sample (adjusted): 1991 2018 } \\
\hline Variable & Coefficient & Std. Error & t-Statistic & Prob. \\
\hline LRGDP & 0.010094 & 0.014875 & 0.678549 & 0.5039 \\
LRMONEY & 0.006963 & 0.033529 & 0.207662 & 0.8372 \\
LRCHANGE & 0.997231 & 0.009759 & $102.1907^{\star *}$ & 0.0000 \\
C & -0.008107 & 0.021121 & -0.38385 & 0.7045 \\
R-squared & 0.997965 & Mean dependent var & 1.646533 \\
Adjusted R-squared & 0.99771 & S.D. dependent var & 1.018334 \\
S.E. of regression & 0.048727 & Sum squared resid & 0.056984 \\
Long-run variance & 0.001789 & & & \\
\hline
\end{tabular}

**Significant at $1 \%$ level.

The cointegration test confirms that there is a long run relationship between the variables, so we can use an Engle Granger Error Correction model (ECM) to estimate the model. 
Equation R2: ECM Long run equation

\begin{tabular}{ccccc}
\hline \multicolumn{5}{c}{ Dependent Variable: LRINF } \\
\hline \multicolumn{5}{c}{ Method: Least Squares } \\
\hline \multicolumn{5}{c}{ Sample (adjusted): 1990 2019 } \\
\hline Included observations: 30 after adjustments \\
\hline Variable & Coefficient & Std. Error & t-Statistic & Prob. \\
\hline C & 6.703594 & 4.858124 & 1.379873 & 0.1794 \\
LRMONEY & 0.052005 & 0.277858 & 0.187163 & 0.8530 \\
LRGDP & 2.459593 & 2.002936 & 1.227994 & 0.2305 \\
LRCHANGE & 1.886541 & 0.705515 & $2.673993^{* *}$ & 0.0128 \\
R-squared & 0.38942 & Sum squared resid & 18.21482 \\
Adjusted R-squared & 0.318978 & F-statistic & 5.527684 \\
S.E. of regression & 0.83700 & Prob (F-statistic) & 0.004509 \\
\hline
\end{tabular}

${ }^{*}$ Significant at $1 \%$ level. LRINF $=\log \frac{\text { waemu average inflation rate }}{\text { wamz average inflation rate }}$;

LRMONEY $=\log \frac{\text { waemu average broad money }}{\text { wamz average broad money }}$;

LRGDP $=\log \frac{\text { waemu gross domestic product }}{\text { wamz gross domestic product }}$;

LRCHANGE $=\log \frac{\text { waemu average exchange rate }}{\text { wamz average exchange rate }}$.

As the results of the long-run equation show, the coefficients are positive as expected. However, only the LRCHANGE variable (exchange rate differential between WAEMU and WAMZ) is significant. It is the only one significant variable explaining the inflation differential between the two blocks. Indeed, the long-run elasticity of the inflation differential with respect to the exchange rate differential is relatively high (0.70), which means that if the exchange rate differential increases by $10 \%$, the inflation differential between the two blocks will increase by $7 \%$.

Equation No. R2: ECM Short run equation

\begin{tabular}{ccccc}
\hline \multicolumn{5}{c}{ Dependent Variable: DLRINF } \\
\hline \multicolumn{5}{c}{ Method: Least Squares } \\
\hline \multicolumn{5}{c}{ Sample (adjusted): 1991 2019 } \\
\hline Included observations: 29 after adjustments \\
\hline Variable & Coefficient & Std. Error & t-Statistic & Prob. \\
\hline C & -0.005374 & 0.011329 & -0.474327 & 0.6396 \\
DLRGDP & -0.030469 & 0.047862 & -0.636606 & 0.5304 \\
\hline
\end{tabular}




\begin{tabular}{ccccc} 
Continued & \multicolumn{3}{c}{} \\
\hline DLRMONEY & $\mathbf{0 . 0 1 7 2 5 5}$ & $\mathbf{0 . 0 5 5 5 8 3}$ & $\mathbf{0 . 3 1 0 4 4 4}$ & $\mathbf{0 . 7 5 8 9}$ \\
DLRCHANGE & $\mathbf{0 . 9 9 6 4 4 8}$ & $\mathbf{0 . 0 0 7 7 8 1}$ & $\mathbf{1 2 8 . 0 6 0 9 * *}$ & $\mathbf{0 . 0 0 0 0}$ \\
Res $(\mathrm{t}-\mathbf{1})$ & $-\mathbf{0 . 9 9 9 8 3 5}$ & $\mathbf{0 . 2 1 7 5 3 2}$ & $-4.5962^{* *}$ & $\mathbf{0 . 0 0 0 1}$ \\
R-squared & 0.99874 & Mean dependent var & 0.065491 \\
Adjusted R-squared & 0.998529 & F-statistic & 4754.10 \\
S.E. of regression & 0.047916 & Prob (F-statistic) & 0.000000 \\
\hline
\end{tabular}

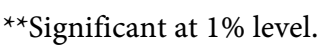

The estimated model is very satisfactory with an Adj $R^{2}$ of 0.99 and the error correction coefficient $(-0.99)$ is negative and significant at the $1 \%$ level. The results of the short term model confirm those of the long term model. The only one significant variable is the exchange rate ratio (DLRCHANGE). So, the exchange rate gap (LRCHANGE) is the most important factor explaining the nonconvergence of inflation rates between the WAEMU and the WAMZ. The fact that this long term elasticity (70\%) is much higher than the short term elasticity (34\%) shows that shocks are quickly absorbed and that there is a rapid adjustment to the long term dynamics. The speed of adjustment in the event of a shock is very high; in fact $99 \%$ of the shock is absorbed after one year.

\section{Conclusion}

Our results demonstrated the absence of Beta and Sigma convergence between ECOWAS countries during the 1990-2020 period. WAMZ countries, due to their flexible exchange rate regimes, had higher inflation rates than their WAEMU counterparts. Indeed, causality tests between inflation and exchange rate revealed that WAMZ countries, unlike WAEMU countries, were victims of the Exchange Rate Pass-Through to inflation.

Neither the difference in the evolution of production nor that of the money supply explains the non-convergence of inflation rates between the WAEMU and WAMZ countries. Non-convergence of inflation rates is significantly linked to the difference in the evolution of exchange rates. Thus, the inflation gap between WAEMU and WAMZ countries is essentially due to the difference in exchange rate regimes.

As long as the WAMZ currencies tend to depreciate against the WAEMU currency i.e. the CFA pegged to the Euro, the respective inflation rates of the two zones cannot converge.

For the WAMZ countries, the solution lies in the stabilization of their exchange rates, a difficult objective for individual countries to achieve separately. They should follow the example of their WAEMU counterparts by rapidly setting up a common monetary zone or a joint mechanism for managing their foreign exchange reserves to avoid exchange rate volatility. However, they could opt to peg their future currency not to a single currency as the WAEMU countries do, but 
to a basket of international currencies as the Euro, the Dollar, the Yen, the Yuan and the Pound Sterling.

\section{Conflicts of Interest}

The author declares no conflicts of interest regarding the publication of this paper.

\section{References}

Akofio-Sowah, N. A. (2009). Is There a Link between Exchange Rate Pass-Through and the Monetary Regime: Evidence from Sub-Saharan Africa and Latin America. International Advances in Economic Research, 15, 296-309. https://doi.org/10.1007/s11294-009-9209-8

Alagidede, P., George, T., \& Anokye, M. A. (2008). Nominal Exchange Rates and Price Convergence in the West African Monetary Zone. International Journal of Business and Economics, 7, 181-198.

Aliyu, S. U. R., Yakub, M. U., Sanni, G. K., \& Duke, O. O. (2010). Exchange Rate PassThrough in Nigeria: Evidence from a Vector Error Correction Model. MPRA Paper 25053.

An, L., Wang, J., Caulker, E., \& Pessima, S. (2011). Exchange Rate Pass-Through: Evidence Based on Vector Autoregression with Sign Restrictions. Globalization and Monetary Policy Institute, Working Paper No. 70, Federal Reserve Bank of Dallas. Journal of Monetary and Economic Integration, 34, 93-123. https://doi.org/10.24149/gwp70

Barro, R. J., \& Sala-i-martin, X. (1995). Economic Growth (2nd ed.). McGraw-Hill.

Butt, B. Z., Rehman, K. U., \& Azeem, M. (2010). The Causal Relationship between Inflation, Interest Rate and Exchange Rate: The Case of Pakistan. Transformations in Business \& Economics, 9, 95-102.

Campa, J. M., \& Goldberg, L.S. (2002). Exchange Rate Pass-Through into Import Prices: A Macro or Micro Phenomenon? Working Paper 8934.

Caselli, F., Esquivel, G., \& Lefort, F. (1996). Reopening the Convergence Debate: A New Look at Cross-Country Growth Empirics. Journal of Economic Growth, 1, 363-389. https://doi.org/10.1007/BF00141044

Devereux, M. B., \& Yetman, J. (2000). Price Setting and Exchange Rate Pass-Through, Theory and Evidence. Bank of Canada.

Diop, M. B., \& Thiaw, K. (2010). Différentiel d'inflation dans une union monétaire: Le cas de l'UMOA. Ministère de l'économie et des finances du Sénégal-DPEE/DEPE Août 2010.

Diop, P. L. (2002). Convergence nominale et convergence réelle: Une application des concepts de s-convergence et de b-convergence aux économies de l'ECOWAS. Notes d'Information No. 531 Déc. 2002 B.

Dornbush, R. (1987). Exchange Rate and Prices. American Economic Review, 77, 93-106.

Dramani, L. (2010). Convergence and Economic Integration in Africa: The Case of the Franc Zone Countries. African Economic Research Consortium, Research Paper 200.

Engel, R. F., \& Granger, C. W. J. (1987). Cointegration and Error Correction: Representation, Estimation and Testing. Econometrica, 55, 251-276.

https://doi.org/10.2307/1913236

Frankel, J. A., Parsley, D. C., \& Wei, S.-J. (2005). Slow Pass-Through around the World: A New Import for Developing Countries? Open Economies Review, 23, 213-251. https://doi.org/10.1007/s11079-011-9210-8 
Frimpong, S., \& Adam, A. M. (2010). Exchange Rate Pass-Through in Ghana. International Business Research, 3, 186-192. https://doi.org/10.5539/ibr.v3n2p186

Garcia, C. J., \& Restrepo, J. E. (2001). Price Inflation and Exchange Rate Pass-Through in Chile. Working Papers No. 128, Central Bank of Chile.

Hahn, E. (2003). Pass-Through of External Shocks to Euro Area Inflation. Working Paper 243, European Central Bank. https://doi.org/10.2139/ssrn.457310

Kiptui, M., Ndolo, D., \& Kaminchia, S. (2005). Exchange Rate Pass-Through: To What Extent Do Exchange Rate Fluctuations Affect Import Prices and Inflation in Kenya? Central Bank of Kenya A Policy Discussion Paper / Working Paper No. 1.

Krugman, P. (1986). Pricing to Market When the Exchange Rate Changes. Working Paper 1926. https://doi.org/10.3386/w1926

Mc Farlane, L. (2002). Consumer Price Inflation and Exchange Rate Pass-Through in Jamaica. Bank of Jamaica.

Ndiaye, M. B., \& Korsu, R. D. (2014). The Quest for a Monetary Union in ECOWAS: An Econometric Test for Convergence of Countries in Private Sector Development in Africa (pp. 31-59). Springer 1994. https://doi.org/10.1007/978-3-319-05188-8_2

Pesaran, M. H., Shin, Y., \& Smith, R. J. (2001). Bounds Testing Approaches to the Analysis of Level Relationships. Applied Econometrics, 16, 289-326.

https://doi.org/10.1002/jae.616

Razafimahefa, I. F. (2012). Exchange Rate Pass-Through in Sub-Saharan African Economies and Its Determinants. IMF Working Paper 12/141 June 2012. https://doi.org/10.5089/9781475503982.001

Rowland, P. (2003). Exchange Rate Pass-Through to Domestic Prices: The Case of Columbia (pp. 106-125). Revista ESPE, No. 47 Diciembre 2004, Banco de la republica de Columbia. https://doi.org/10.32468/Espe.4703

Rraji, R. O. (2013). Exchange Rate Pass-Through in a Small Open Economy: A Case Study of West African Monetary Zone. Journal of Global Economy, 9, 275-290. https://doi.org/10.1956/jge.v9i4.301

Sims, C. A., Stock, J. H., \& Watson, M. W. (1990). Inference in Linear Time Series Models with Some Unit Roots. Econometrica, 58, 113-144. https://doi.org/10.2307/2938337

Solow, R. M. (1956). A Contribution to the Theory of Economic Growth Author(s). The Quarterly Journal of Economics, 70, 65-94. https://doi.org/10.2307/1884513

Takatoshi, I., \& Sato, K. (2008). Exchange Rate Changes and Inflation in Post-Crisis Asian Economies: Vector Autoregression Analysis of the Exchange Rate Pass-Through. Journal of Money, Credit, and Banking, 40, 1407-1438. https://doi.org/10.1111/j.1538-4616.2008.00165.x

Tanimoune, N. A., \& Semedo, G. (2011). Inflation et objectif de monnaie unique dans les pays de la CEDEAO: Convergence nominale versus variabilité relative des prix. Cahiers économiques de Bruxelles, 56, 261.

Tarawalie, A. B., Sissoho, M., Conte, M., \& Ahortor, C. R. (2012). Exchange Rate, Inflation and Macroeconomic Performance in the Wamz. WAMI Occasional Paper Series No. 2. 


\section{Annex}

1. The economic community of (15) west African member states: ECOWAS

\begin{tabular}{ll}
$\begin{array}{l}\text { West African Economic and } \\
\text { Monetary Union-WAEMU }\end{array}$ & \multicolumn{1}{c}{$\begin{array}{c}\text { West African Monetary Zone } \\
\text { WAMZ }\end{array}$} \\
\hline 1-BENIN & 9 -THE GAMBIA \\
2-BURKINA FASO & 10 -GHANA \\
3-CÔTE D'IVOIRE & 11 -GUINEA Rep. \\
4-GUINEA BISSAU & 12 - LIBERIA \\
5-MALI & 13 -NIGERIA \\
6-NIGER & 14 -SIERA LEONE \\
7-SENEGAL & 15 -CABO VERDE \\
8-TOGO & \\
\hline
\end{tabular}

\section{Definition of the model variables}

$$
\begin{gathered}
\text { LRINF }=\log \frac{\text { waemu average inflation rate }}{\text { wamz average inflation rate }} \\
\text { LRMONEY }=\log \frac{\text { waemu average broad money }}{\text { wamz average broad money }} \\
\text { LRGDP }=\log \frac{\text { waemu gross domestic product }}{\text { wamz gross domestic product }} \\
\text { LRCHANGE }=\log \frac{\text { waemu average exchange rate }}{\text { wamz average exchange rate }}
\end{gathered}
$$

\section{Causality tests}

Sample: 19902021

\begin{tabular}{cccc}
\hline Lags: 1 & & & \\
\hline Null Hypothesis: & Obs & F-Statistic & Prob. \\
\hline LRMONEY does not Granger Cause LRINF & 29 & 4.15509 & 0.0518 \\
LRINF does not Granger Cause LRMONEY & & 0.89554 & 0.3527 \\
LRGDP does not Granger Cause LRINF & 29 & 4.02628 & 0.0553 \\
LRINF does not Granger Cause LRGDP & & 0.20926 & 0.6511 \\
LRCHANGE does not Granger Cause LRINF & 29 & 7.29819 & $\mathbf{0 . 0 1 2 * *}$ \\
LRINF does not Granger Cause LRCHANGE & & 0.66711 & 0.4215 \\
LRGDP does not Granger Cause LRMONEY & 29 & 0.73851 & 0.3980 \\
LRMONEY does not Granger Cause LRGDP & & 0.93470 & 0.3426 \\
LRCHANGE does not Granger Cause LRMONEY & 29 & 2.72692 & 0.1107 \\
\hline
\end{tabular}


Continued

\begin{tabular}{|c|c|c|c|}
\hline LRMONEY does not Granger Cause LRCHANGE & & 1.71898 & 0.2013 \\
\hline LRCHANGE does not Granger Cause LRGDP & 29 & 0.00109 & 0.9740 \\
\hline LRGDP does not Granger Cause LRCHANGE & & 1.10180 & 0.3035 \\
\hline
\end{tabular}

\section{Descriptive statistics of the variables}

\begin{tabular}{ccccc}
\hline & LRGDP & LRINF & LRMONEY & RCHANGE \\
\hline Mean & -2.558183 & 1.638123 & -0.046837 & 2.218483 \\
Median & -2.604653 & 1.433221 & -0.161560 & 2.433821 \\
Maximum & -2.257975 & 4.908878 & 2.516326 & 4.490065 \\
Minimum & -2.829002 & -0.046418 & -1.622366 & 0.815626 \\
Std. Dev. & 0.190515 & 1.014250 & 1.227369 & 1.139630 \\
Skewness & 0.069226 & 1.100946 & 0.450611 & 0.313181 \\
Kurtosis & 1.529417 & 4.904306 & 1.961969 & 1.958328 \\
Jarque-Bera & 2.727230 & 10.59339 & 2.362136 & 1.846762 \\
Probability & 0.255735 & 0.005008 & 0.306951 & 0.397174 \\
Sum & -76.74548 & 49.14368 & -1.405104 & 66.55449 \\
Sum Sq. Dev. & 1.052585 & 29.83241 & 43.68662 & 37.66397 \\
Observations & 30 & 30 & 30 & 30 \\
\hline
\end{tabular}

\section{Beta convergence results}

\begin{tabular}{cccc}
\hline \multicolumn{5}{c}{ Dependent Variable: INFWAMZ } \\
\hline \multicolumn{5}{c}{ Method: Least Squares } \\
\hline \multicolumn{5}{c}{ Dample (adjusted): 1991 2019 } \\
\hline & Included observations: 29 after adjustments & Prob. \\
\hline Coefficient & Std. Error & t-Statistic & 0.9240 \\
\hline Variable & -0.004968 & 0.051577 & -0.096315 \\
R-squared & -0.000517 & Mean dependent var & -0.171531 \\
Adjusted R-squared & -0.000517 & S.D. dependent var & 5.993166 \\
S.E. of regression & 5.994715 & Akaike info criterion & 6.453508 \\
Sum squared resid & 1006.225 & Schwarz criterion & 6.500656 \\
Log likelihood & -92.57586 & Hannan-Quinn criter. & 6.468274 \\
Durbin-Watson stat & 2.625939 & & \\
\hline
\end{tabular}

INFWAMZ = Average Inflation in WAMZ. 
Dependent Variable: INFWAEMU

Method: Least Squares

Date: 11/01/21 Time: 08:27

Sample (adjusted): 19912019

Included observations: 29 after adjustments

\begin{tabular}{ccccc}
\hline Variable & Coefficient & Std. Error & t-Statistic & Prob. \\
\hline INFWAEMU $\left._{\mathrm{t}-1}-5 \%\right)$ & -0.170259 & 0.375353 & -0.453598 & 0.6536 \\
R-squared & 0.007162 & Mean dependent var & 0.139048 \\
Adjusted R-squared & 0.007162 & S.D. dependent var & 12.24690 \\
S.E. of regression & 12.20296 & Akaike info criterion & 7.875109 \\
Sum squared resid & 4169.544 & Schwarz criterion & 7.922257 \\
Log likelihood & -113.1891 & Hannan-Quinn criter. & 7.889875 \\
Durbin-Watson stat & 1.771039 & & \\
\hline
\end{tabular}

INFWAEMU $=$ Average Inflation in WAEMU. 